\title{
Adoption of digital banking channels in an emerging economy: exploring the role of in-branch efforts
}

\author{
Simran Jit Kaur ${ }^{1} \cdot{\text { Liaqat } \mathrm{Ali}^{1} \cdot \text { M. Kabir Hassan }}^{2} \cdot$ Md Al-Emran $^{3}$
}

Received: 22 April 2019 / Revised: 8 November 2020 / Accepted: 19 November 2020 / Published online: 17 February 2021

(c) The Author(s), under exclusive licence to Springer Nature Limited part of Springer Nature 2021

\begin{abstract}
The aim of this qualitative study is to analyse the role of in-branch efforts of banks on migrating customers from branch banking to digital banking in India. In-depth semi-structured interviews were conducted with bank executives representing senior management from public and private sector banks in India. Qualitative content analysis technique was used to analyse the data. Varieties of responses received during interviews were clubbed into four main themes based on data reduction, display, and conclusion-drawing processes. In-branch communication with customers, digital transformation of the branch, customer-centric initiatives, and redefined role of branch staff hold the potential to bridge the customers' migration to digital banking. The paper suggests that the key identified factor in improving digital banking acceptance in India is the requirement of integrated cultural and organisational changes at the bank's level to gain the customers' confidence and trust in digital banking.
\end{abstract}

Keywords Digital banking $\cdot$ Communication $\cdot$ Branch transformation $\cdot$ In-branch efforts $\cdot$ Branch staff

\section{Introduction}

In the last few decades, huge investments have been made by banks in technology to reduce their cost and improve customer's experience. Banks are offering digital banking channels such as ATM, Internet banking, mobile banking, digital banking kiosks to deliver best quality services to customers with the expectation of increasing profitability and reducing operating cost (Sarel and Marmorstein 2003). It is observed that the bank's costs reduce with the shift of

Liaqat Ali

draliliaqat@gmail.com

Simran Jit Kaur

sjkbawa@gmail.com

M. Kabir Hassan

mhassan@uno.edu

Md Al-Emran

malemran@mcneese.edu

1 School of Management Studies, Punjabi University, Patiala, Punjab, India

2 Department of Economics and Finance, University of New Orleans, New Orleans, LA 70148, USA

3 McNeese State University, Lake Charles, LA 70609, USA a major chunk of customers to modern banking channels (Howcroft et al. 2002). However, the expected reduction in operating expenses has not been achieved yet by the banks as they are still struggling to move customers towards digital banking channels (Sarel and Marmorstein 2002; DeYoung et al. 2007; He et al. 2019). The situation is much critical for emerging countries such as India where only $16 \%$ of the rural population use the Internet for making digital payments (Pandey 2018).

According to the report released by Gartner, IT expenditure by securities and banking firms in India has reached $\$ 9.1$ billion with a growth of $11.7 \%$ (Shetty 2017). Further, the total IT expenditure is expected to reach $\$ 11$ billion in 2020 (Gartner 2019). However, the return on investment of Indian banks in technology is just $12 \%$ of US banks due to the low rate of digital banking acceptance (Sinha and Mukherjee 2016). At the same time, it is worth mentioning that the cash transactions cost is $1.7 \%$ of Indian GDP which puts a huge burden on the economy (Bakshi 2016). In this regard, the Government of India initiated the 'Digital India' campaign in 2015 to empower people digitally. The success of the 'Digital India' campaign is apparent from the fact that more than a billion Indian citizens have a digital identity with 560 million Internet connections (Kumar 2019). The purpose of digitisation is to bring disconnected rural remote 
regions into the formal financial sector through electronic banking channels which in turn will contribute to economic development. Digital banking mediums help to connect the underserved masses with mainstream banking system by offering various innovative banking services. The modern mobile banking apps also enable customers to use nonfinancial services. However, due to the lack of awareness and knowledge, these services have not been fully utilised by customers (Shaikh et al. 2020). Certainly, there is a dire need to positively influence customers about the usability of modern banking channels and persuade them to migrate to digital channels (Figs. 1 and 2).

Banks in India need to understand that making huge investments in technology is not enough unless most bank customers adopt it for banking transactions. As rightly argued by Shaikh and Karjaluoto (2016) that digital banking is much more than an innovative banking channel and a convincing marketing strategy. The term digitisation has brought a significant change in how banks understand and satisfy its customers' needs. In India, efforts have been made by the banks to persuade customers to adopt digital banking channels such as intensive digital marketing campaigns to educate customers about modern channels, but still, the adoption rate is not as expected (Patel and Patel 2018). Since bank branches provide an opportunity to the bank to communicate and persuade customers personally by demonstrating the proposed benefits of adopting modern banking channels, the present study exhibits the need for Indian banks to focus upon implementing serious in-branch effort. It is the high time for banks to identify cost-effective in-branch strategies to connect the masses with digital banking channels, though this area is under-researched. In this regard, the present study attempts to evaluate the bank executives' perceptions regarding the effectiveness of in-branch efforts of banks to persuade the customers to adopt and use digital banking channels.

The earlier studies conducted in the area of digital banking have mainly explored the attitude of customers and antecedent variables that matter to customers while using digital banking channels or the factors impacting the intention of customers' to use the modern banking channels (Montazemi and Qahri-Saremi 2015; Szopiński 2016; Alalwan et al. 2017; He et al. 2019). But surprisingly, rarely a study in India has given attention to study the impact of the bank's initiatives within the branch to encourage customers to adopt modern banking channels.

The present study tries to close this research gap by answering the following research question:

RQ: How In-branch experience and technological initiatives can contribute to the adoption of digital banking channels by customers.

To answer this research questions, we draw on TAM (technology acceptance model) to analyse how in-branch efforts of banks can contribute to enhancing customers' perceived usefulness (PU) and ease of use (PEOU) which positively influences customers' attitude towards technology acceptance. Also, the analysis is guided by additional antecedents' variables identified by extended TAM proposed by various researchers and scholars in the context of adopting self-service banking technology.

The empirical data for the qualitative study are based on in-depth interviews conducted with 22 bank executives from public and private sector banks in northern urban India. The recent report by Vater et al. (2019) strongly highlights the struggle for banks at present to migrate customers to digital channels. Due to huge investments involved in the digital banking platform, ensuring the adoption and usage of these channels is an important goal of the banks. The study elucidates the need to transform future bank branches by identifying cost-effective strategies and segmenting the branch customers on the basis of their banking needs and preferences. The present study contributes to the literature by studying how personalisation and in-branch initiatives should be strengthened by the bank managers to build customers' initial trust in
Fig. 1 Research framework (adapted from Davis 1989; Lee et al. 2007; Yap et al. 2010)

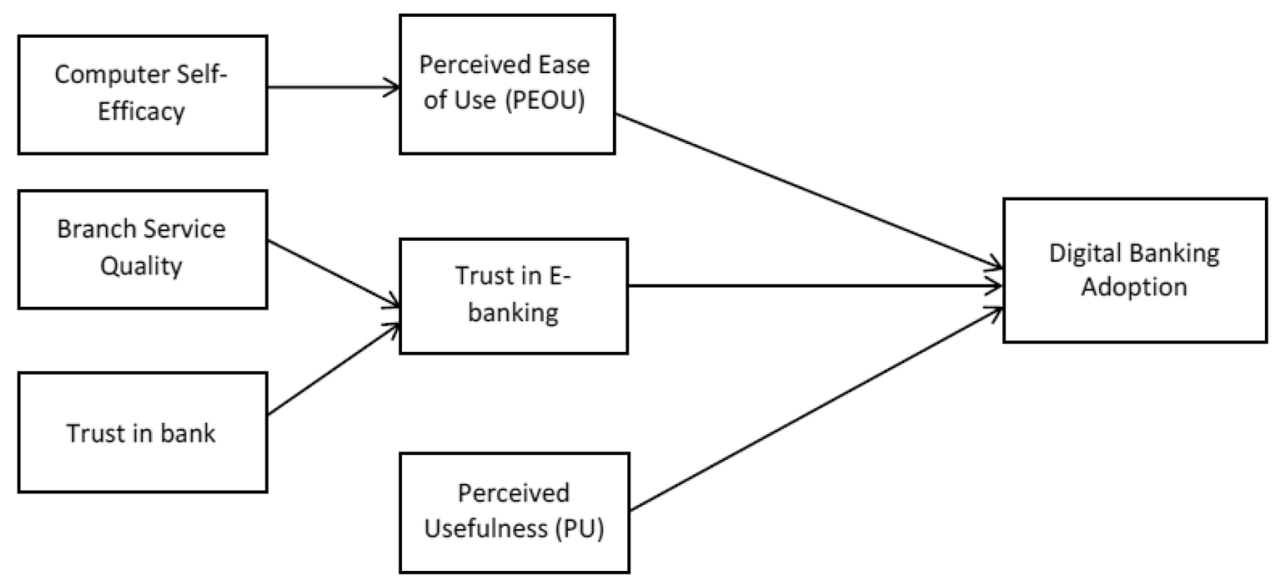


digital banking channels. The study also contributes to identifying various integrated cultural and organisational obstacles particularly in public sector bank branches which hinder the customers' adoption of digital banking. The study begins with a review of the literature on customer technology acceptance for banking transactions. In the later section, we describe the conceptual framework for analysing interview data based on TAM (Davis 1989) and its extensions propounded in context of adopting self-service banking technology, followed by research methodology section. The following section describes the findings in terms of identified themes and concludes with the discussion of findings.

\section{Status of digital banking adoption in India}

Technology has transformed the banking industry all over the world. However, the adoption rate of technologyenabled banking services varies across different countries (Takieddine and Sun 2015). In India, almost all banks offer digital banking services to their customers as a strategic tool to survive in the market (Safeena et al. 2014). With the growth of investment in technology by financial service providers in India, it becomes highly important to understand the perceptions of customers and designing the strategies accordingly (Roy et al. 2017).

Post demonetisation (invalidation of large currency notes) Government of India has launched various efforts to migrate customers to digital payment channels from cash (e.g. e-Wallets, Unified Payment Interface, Aadhaar-enabled payment system, etc.). As per the report of Reserve Bank of India (RBI) on digital transactions, the total volume of non-cash transaction in India has reached 1.9 billion in 2016-2017 from 228.9 million in 2004-2005. Despite this rapid growth, the largest public sector bank (SBI) in India has reported only $5.86 \%$ mobile banking users and $9.69 \%$ of Internet banking users in its recent annual report 2016-17. Thus, only informing or spreading awareness would not shift customers towards digital banking but requires changes in the implementation process and successful implementation depends upon how well these technological advancements are communicated to customers (Sarel and Marmorstein 2002).

The point of utmost importance is that in India the challenge is not just migrating customers from traditional banking channels to digital channels but also to connect the unbanked masses with the mainstream banking system using digital finance. Undoubtedly, digital mediums have increased the level of financial inclusion globally from $51 \%$ in 2011 to 69\% in 2017 (Global Findex Database 2017). But the fact which differentiates the developing and emerging economies from developed economies is the adoption and use of digital banking channels from the consumer end. Apparently, in high-income economies, 91\% of adults use digital payment method, while in developing economies just $44 \%$ of adults make digital payment through their account (Global Findex Database 2017).

India is an emerging economy wherewith the launch of digitisation campaign (2015) and implementation of demonetisation (2016) the significant chunk of the population is shifted quickly from traditional banking channels to digital channels. However, education, lack of infrastructure and strong Internet connectivity are the issues which hinder the adoption of digital banking channel in India (Tiwari 2019). As per statistics, $80 \%$ of Indians have a bank account (The Economic Times 2018a, b). However, World Bank reported (2017) that $48 \%$ of the total 310 million accounts opened in India from 2014 to 2017 are inactive. The lower than anticipated regular usage of digital mediums for banking transactions calls for more in-depth and critical research on formulating the strategies and practices to migrate customers to technology-enabled banking channels based on the factors that matter to customers the most.

\section{Conceptualisation of in-branch efforts and technology acceptance}

The literature on digital banking is replete with examining the customers' attitude (Pikkarainen et al. 2004; Eriksson et al. 2005; Ibrahim et al. 2006; Walker and Johnson, 2006; Poon 2007; Alalwan et al. 2016; Sánchez-Torres 2018) and factors affecting the acceptance of digital banking services (Montazemi and Qahri-Saremi 2015; Szopiński 2016; Alalwan et al. 2017). Few studies have also explored the impact of technology on the bank-customer relationship (Harden 2002; Durkin and Howcroft 2003). Further, Karjaluoto et al. (2018) highlighted the impact of investment in mobile financial services apps (MFSAs) on improved bank-customer relationships. Even in India vast number of studies have been conducted on customers' behavioural factors (Malhotra and Singh 2010; Singh and Kaur 2011; Sinha and Mukherjee 2016) with regard to technology acceptance in the banking industry. However, very scanty literature is available on understanding the significance of in-branch efforts of banks to migrate customers to adopt digital banking channels. Impact of in-branch communication with the customers about technology-driven efforts has received hardly any attention of scholars in India.

In reference to the present study, the in-branch efforts are "the services provided at branch level to make customers comfortable with digital channels by imparting firsthand knowledge of technology-enabled banking services". 
Sarel and Marmorstein (2002) were among the pioneering researchers who highlighted the role of communication at branch level to migrate customers to digital banking channels. They opined that effective communication with customers at the branch for persuading them to use digital banking channels can make a difference in their perception and attitude. It is worth mentioning that Former RBI governor Raghuram Rajan (2015) had also emphasised the significance of communicating the banking products and services to customers in regional language to connect the bank with its customers:

It is the responsibility of the government and the banking sector to provide banking facilities to those who have money but have no access to formal banking channels in a language that they would understand. We should also arrange for financial literacy in the language that they understand.

Previous studies have already reported high bank branch footfall in Indian banks. A survey report by Schofield and Chew (2013) on future of bank branch in Asian banks established that an average bank customer in India makes 28 branch visits in a year which is very high as compared to developed countries like Australia, UK and the USA. Similarly, Avaya (2017) surveyed 5000 banking customers from UK, Australia, UAE and India. The survey reports that $51 \%$ of Indian bank customers still prefer to visit their branch regularly which is highest among the four countries surveyed.

Further, Marous (2013) identified that encouraging customers to change the current banking channel is a difficult venture. Similarly, Karjaluoto et al. (2019) asserted that customers' intention to use contactless payment systems is highly influenced by habit and it is hard to change such behaviours. The best alternative at this stage that the bank could have is to set up an optimal channel mix to meet customers banking needs. Banks can educate their customers about online banking channels in the branch or online using interactive kiosks and tablets. Incentives for using online banking channel can persuade the customers to use these channels in the future (Accola 1996). Further, Brunier et al. (2015) opined that banks can reduce their cost and improve technology adoption rate by educating customers using in-branch interactive screens and branch employees can make customers familiar with technologyenabled banking services during their visit in the branch. They further reported that in the era of technology the significance of bank branch cannot be overlooked since customers still prefer branch network for taking highly specialised advisory services to buy high-value and complex products such as investment and mortgage.

In a recent study, Yu and Hughes (2016) highlighted the significance of in-branch ATMs and kiosks to successfully migrate customers to digital channels. The authors revealed that banks need to identify the customer segments as per their banking needs and channel preference to create a unique channel mix. Similarly, the cognizant survey (2016) reported that bank branches can serve as the best platform to interact with the customers and influence them positively. The best customer experience at branch travels across other banking channels. Dallerup et al. (2018) defined various formats of smart branches in a digital era based on location. Four categories of bank branches such as Box branch, Standard branch, Segment branch and Flagship branch are suitable for areas with specific attributes. At the same time, branch employees need to be trained to perform multiple analytical tasks to improve bank performance.

Schofield and Chew (2013) revealed that most of the branch visits in Asian countries involve routine banking transaction which increases the cost and can easily be performed online. Thus, the biggest challenge for the banks is to divert the customers from branch banking to digital banking in an interactive way. The fact that in the era of the technology bank branches will continue to serve customers' high-value and complex banking needs is well established in the literature (Luchetti 2017; Joyce 2017). Since the strong human relationship is the base of business in most of the Asian cultures (Rotchanakitumnuai and Speece 2003), the study attempts to concentrate on efforts to improve the online banking acceptance by maintaining the human touch. The study was initiated to highlight the need for banks to recognise the potential of in-branch initiatives to persuade customers to use technology-enabled banking channels and how banks can improve its online banking customer base by convincing its existing branch visiting customers about the usefulness of digital banking channels. There is no doubt that digital channels hold the potential to improve customer experience and banks have already invested hugely in technology.

The acceptance rate of digital banking channels in India is much lesser than anticipated (Patel and Patel 2018). The question is why banks are still struggling to move customers to digital banking channels even after making a huge investment in technology. Even in the USA, 38\% of customers reported preferring bank branches or ATMs to other digital banking channels in a recent survey conducted by McKinsey Consumer Insight (2016). The matter of fact is that the company cannot always allow its customers to follow their preferences as this leads to an increase in the cost (Myers et al. 2004). This scenario brings light to focus on directing the customers to adopt the right channel mix for products and services. The first thing that banks can start with is transforming or modernising the bank branches to satisfy the needs of customers (Cognizant 20-20 Insights 2016). More specifically in India where the acceptance rate is already so low and digital banking is in its nascent stage. 


\section{TAM and digital banking adoption}

In order to analyse the impact of in-branch efforts on the adoption of digital banking in India, the study draws upon the technology acceptance model (TAM) (Davis 1989). This is the highly accepted model to study the users' attitude to technology by analysing perceived usefulness (PU) and perceived ease of use (PEOU), the two main determinants of users' behaviour towards technology. Here, perceived usefulness (PU) is the degree to which the potential customer believes the new technology to improve his/her performance and perceived ease of use (PEOU) is concerned with prospective customers' perception that new technology will reduce the efforts required (Davis 1989). TAM has been very well accepted and validated in a number of studies worldwide in the context of technology adoption (Taylor and Todd 1995; Wang et al. 2003; Pikkarainen et al. 2004; King and He 2006). Therefore, TAM provides a valid approach for our study to understand the adoption of digital banking in the Indian context. Also, the analysis is guided by additional antecedents' variables identified by extended TAM proposed by various researchers and scholars in the context of adopting self-service banking technology.

Our review of related studies from developing countries mainly demonstrates the extension of technology acceptance model (TAM) (Davis 1989) based on cultural attributes and individual characteristics of consumers, as it has been believed by various researchers that basic TAM ignores the impact of external influences such as cultural and infrastructure availability on adoption pattern. For instance, evidence from the Middle East as provided by Sukkar and Hassan (2005) highlights the need to include cultural factors from the consumer side and technical quality from bank side to the existing TAM in order to make it more relevant in the context of developing countries. In the same line, Tobbin (2012) identified two additional variables such as economic factor and trust apart from TAM variables that matter to unbanked customers in Ghana while adopting mobile banking services.

Evidence from India brings light on the impact of computer self-efficacy, i.e. the ability to use computers, quality of Internet connection, Internet banking awareness and social influence apart from basic TAM variables on customers' adoption of Internet banking (Sharma and Govindaluri 2014). In another study conducted by Nath et al. (2013) from the perspective of bank employees, three additional factors, namely computer self-efficacy, social influence, technological facility in terms of infrastructure, were reported as an extension to TAM variables in the Indian context. Banu et al. (2019) identified ease of use and self-efficacy as major drivers of technology adoption in India. Researchers reported a direct link between trust, offline service quality and adoption of technology (Patricio et al. 2003; Lee et al. 2007; Bashir and Madhavaiah 2015). Lack of required infrastructure and connectivity and trust has been reported as the major inhibitor for technology adoption in India (Nath et al. 2013; Sinha and Mukherjee 2016). In previous studies, traditional service quality in the bank has been viewed as an enabler to build customers' trust in e-banking services which in turn influences customers' adoption of e-banking. For example, Yap et al. (2010) were the pioneer researchers who explored the impact of offline service quality provided in the branch on the adoption of digital banking channels. Later on, Chiou and Shen (2012) highlighted the significance of offline environment on Internet banking acceptance.

Following the same thought, we proposed research framework for our study to analyse the bank executive's perceptions of how in-branch efforts of banks in India can influence the adoption of digital banking based on some key identified factors from the literature to make it more relevant in the Indian context. Table 1 provides an overview of the predictors of technology adoption. In order to shift customers towards digital banking channels, we identify some most significant factors for the adoption of technology by customers in India. These factors were further used for coding the interview responses and identifying relevant themes for analysis purpose.

\section{Data methodology}

The current study attempts to qualitatively analyse the perceptions of the bank executives from public and private sector banks in India, working at branch level and well-versed with the bank's operational and marketing strategies. Faceto-face interviews were conducted to collect the responses from the respondents between October 2017 and February 2018. The purpose is to get deeper insights into what bank executives perceive, experience and believe regarding the effectiveness of in-branch efforts on consumers' attitude to adopt technology-enabled banking channels.

There are two reasons for selecting the qualitative approach: the dearth of empirical research (Hirschman 1986) in India on exploring the potential of in-branch efforts to promote digital banking channels and the flexibility which qualitative approach extends to deeply investigate complex relationships (Healy and Perry 2000).

\section{Sample selection}

Bank executives were selected from the public sector (State Bank of India, Punjab National Bank) as well as the private sector (Axis and HDFC). Bank executives have been selected as respondents as they possess a better understanding of ground reality due to extensive experience of the banking industry. Geographically, the study concentrates on 
two states from the Northern part of India where information technology (IT) hubs of north India are situated. As in most of the qualitative studies, purposive sampling technique was used to select the respondents from various banks. In total, 35 bank executives representing senior management from public and private banks were approached, but 13 bankers refused to participate in the study. Sample organisations (Banks) selected for the study represent the top banks in India in terms of market share and IT investment.

\section{Data collection and analysis}

In total 22 face-to-face interviews were conducted, out of which 12 were with public sector managers and 10 with private sector bank managers. The high response rate $(62 \%)$ indicates the willingness of bankers to share their experiences and perceptions on the topic. One interviewee from public sector bank had previous work experience with a private sector bank. This helped to attain the unique set of perspectives regarding differences among in-branch practices of public and private sector banks in India. Most of the interviews lasted for an average of 25-30 min. Interviews were conducted in the English language. Most of the bank managers were not comfortable with the tape recording of the interview, so detailed notes were prepared to record the responses of the managers. During the fieldwork, it was observed that most of the bank branches were quite busy and the staff was fully occupied specifically in case of the public sector banks. Due to heavy rush and long queues in most of the bank branches, it was hard to take the time of bank managers for interview. However, with repeated visits and strong potential of the subject matter for improving banking experience, we managed to get insights of bank managers on the topic.

During interview sessions with bank executives basically, three areas were covered
(1) Their perception regarding technological interventions in the banking industry and how technology has changed working experience in the bank;

(2) In-branch efforts undertaken by the bank for persuading customers to use innovative digital banking channels if any;

(3) Can these efforts bring a positive change in customers' attitude and perception towards technology-enabled banking channels and how?

The interviews were semi-structured in nature, and various other related questions were asked loosely to allow flexibility and get maximum insights. Appendix Table 3 gives an outline of the semi-structured interview.

Qualitative content analysis technique (Mayring 2000) was used for the analysis of interview data. Extensive notes were prepared during interview sessions. Varieties of responses received during interviews were clubbed into four main themes using NVIVO 9 software, based on data reduction, display and conclusion-drawing processes (Miles and Huberman 1984).

For the analysis purpose, both inductive and deductive technique was used for identifying themes. Firstly, using the deductive technique the TAM aspects were explored based on the research question and theoretical concepts (Davis 1989; Lee et al. 2007; Yap et al. 2010) and then the codes were identified. Following the coding process, the second, third and fourth author refined the codes based on their suggestions but did not identify new codes. An inductive approach was used to connect the codes and identify themes relating to in-branch communication, branch staff roles, customer-centric initiatives and digitally driven branches with the human touch. Table 2 provides an overview of the coding criteria and theme identification process of the study.

Table 1 Predictors of technology adoption

\begin{tabular}{|c|c|c|}
\hline Construct & Definition & Reference studies \\
\hline Perceived ease of use & $\begin{array}{l}\text { The degree to which the potential customer believes } \\
\text { the new technology to improve his/her performance }\end{array}$ & $\begin{array}{l}\text { Davis (1989), Pikkarainen et al. (2004), Nath et al. (2013), Roy } \\
\text { et al. (2017) }\end{array}$ \\
\hline Perceived usefulness & $\begin{array}{l}\text { Concerned with prospective customers' perception } \\
\text { that new technology will reduce the efforts required }\end{array}$ & Davis (1989), Nath et al. (2013), Roy et al. (2017) \\
\hline Computer self-efficacy & Customers' ability to use computer applications & Wentzel et al. (2013), Nath et al. (2013) \\
\hline Branch Service Quality & Traditional service quality at the bank branch & Yap et al. (2010) \\
\hline Trust in Bank & Trust in services provided by the physical bank & $\begin{array}{l}\text { Lee et al. (2007), Yap et al. (2010), Chiou and Shen (2012), } \\
\text { Yiga and Cha (2014), Bashir and Madhavaiah (2015), Sinha } \\
\text { and Mukherjee (2016); }\end{array}$ \\
\hline Trust in E-banking & Trust in online banking services provided by the bank & Bashir and Madhavaiah (2015), Sinha and Mukherjee (2016) \\
\hline
\end{tabular}




\section{Findings}

\section{In-branch communication with customers}

Communication at the branch to educate customers about online banking channels with either self-service technology like Internet kiosks or specialised bank staff was the dominant factor reported by interviewees. Majority of interviewees believe that effective communication at branch level to guide customers for using technology to fulfil their banking needs can bring a positive change in customers' perception, specifically in rural and semi-urban areas where customers rarely have hands-on experience in computers and Internet.

It is worth mentioning that no direct question regarding communication was asked to respondents during the interview. However, 13 out of 22 bankers agreed that communication with customers at the branch is a key effort to bring positive change in current trends. A typical comment from Banker 1 was:

There is no better approach than interacting with customers about modern technology-based banking channels; it is as much important as handling their (customers) queries atthe branch. As banks have already invested hugely in technology.... its acceptance is pertinent to banks.

Most of the bankers in rural and semi-urban areas were highlighting the need for live demonstration at bank branches and communicating the benefits of online banking channels to customers. But surprisingly, when asked about live demonstration practices at their institutions, there were only a few bankers who agreed to have interactive screens in the bank to educate customers about using digital banking. A colleague from the same bank argued that:

There is need to make strategical changes, with shrinking staff level and heavy branch footfall it is next to impossible for us (Bankers) to initiate personalise interactive sessions with customers regarding how to use technology-enabled banking channels. Dedicated digital tech experts in every branch especially in rural branches can help customers to make maximum use of online banking channels (Banker 6).

Customer satisfaction was observed by respondents as an important factor while demonstrating the use of online banking channels at the bank branch. Enduring relationship of the bank with its customers is the result of regular communication (Howcroft et al. 2002; Waite and Harrison 2002). Previous studies have already established the significance of possessing communication skills along with technical knowledge about the product by the sales force to provide maximum satisfaction to the customer (Goff et al. 1997).
Our research findings also highlight that the introduction of new banking channels requires bankers to gain expertise not only in banking technology but also in communication skills to educate customers to use innovative banking channels, as customers' trust in online banking is the positively related to effective communication among bank and its customers (Mukherjee and Nath 2003). One of the interviewees commented:

That first experience of customers with online channels defines their future chances of using it and effective interactive sessions at bank branch have great chances to make this first experience positive.... But again, it requires dedicated expert staff which most of our bank branches lack (Banker 19).

Another concerning issue which bank executives brought up during the study is using different communication approaches for different segments of customers. Various segments of bank customers exist based on their attitude and expected benefits (Machauer and Morgner 2001). The interview data suggest that with limited trained experts it is not feasible for banks to target all branch visiting customers for migrating to online banking channels. One bank executive from a private sector bank suggests that branch managers can segment customers based on customers' frequency of branch visit. High-cost customers who visit branch more frequently can be targeted on the priority basis with hightouch and demonstrative communication approach to reduce the workload significantly. Thus, the challenge for banks is to identify the most appropriate mode of communication to interact with different segments of customers to convince them to adopt digital banking channels.

\section{Redefining the role of branch staff}

Many of the branch managers (16/22) reported that technology has redefined the role of branch staff in the digital era. Bankers perceive that by equipping branch staff with right soft skills and competencies in technology to solve the issues of customers and improve their banking experience, banks can expedite the online banking adoption in a more effective manner. Bank executives shared their perception about pressing need for changing the role of bank staff due to technological interventions in the banking sector. Banker 15 presented his views regarding internal challenges:

I believe ourworkforce performs multiple jobs at a time like advice customers on high-value products, handles daily transactions but still I am not sure our efforts are enough to equip our staff with right skills to optimally utilize technology and branch space to develop a close relationship with customers and improve branch productivity. 


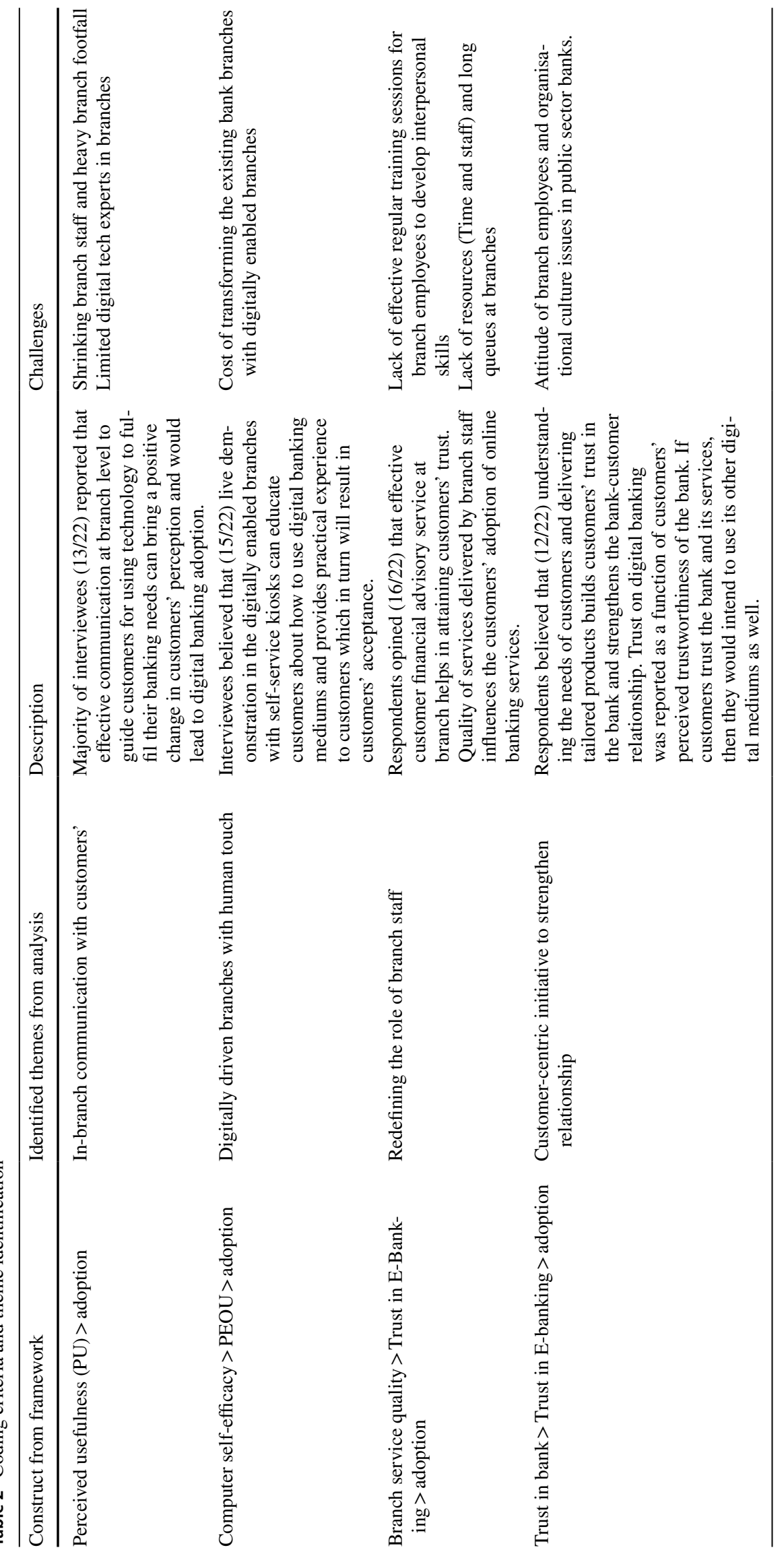

桨 
However, during interviews, it was observed that the scenarios are quite different between public and private sector banks in India. When asked "If there is any special front desk for a relationship manager to provide advisory services in the branch", $85 \%$ respondents from public sector banks responded negatively. Branch staff role in public sector banks was still found to be confined to handling queries of customers with no specific front counter for the relationship manager to extend personal advisory services to customers at the branch. On the flip side, private sector bank branches demonstrate financial advisory services provided by trained personal advisor designated as the Relationship manager.

One interviewee who had previous experience with a private sector bank explained:

Technology has changed the way banking is done within the branches, but when it comes to encouraging people to adopt technology in an engaging way... public sector banks have a long way to go (Banker 5).

Interestingly, public banks in India are very available in remote and rural areas, unlike private banks. They handle much of total bank accounts in the country. We find that front desk staff in public banks lack adequate customer bonding. Since branch service quality influences the customers' adoption of online banking services (Yap et al. 2010), there is need for these banks to focus on training their staff with interpersonal skills to become more productive and effective. This finding is also supported by Kaur et al. (2012) in a previous study in which they highlighted the significance of training the bank employees as per bank's future strategies and plans to improve their job commitment. In this regard one interviewee from major public sector bank confesses:

In the era of technology, we need to establish a closer link between employees and customers if we want to see positive results. The workforce at the branch needs to be trained digitally to educate customers about new banking products and channels (Banker 6).

A colleague from the same bank argues that most of the branch visiting customers of public sector banks belong to a low-income group and lack even basic knowledge about banking activities and these customers generally engage staff with regular activities which can easily be done online. It was observed that lack of resources (time and staff) and long queues at branches make the situation more critical for public sector banks. However, proper training for branch staff to develop a positive attitude towards technology (Lymperopoulos and Chaniotakis 2004) and educating customers to use digital banking channels can help to serve the purpose for both parties.

\section{Customer-centric initiatives to strengthen the relationship}

Another important observation during interviews with bank executives was concerned with understanding individual customers' preferences and needs at the branch. Bank executives described it as permanent pressure for improving customer services to survive in the present volatile and competitive market. Prior studies have also observed that offline fulfilment for customer satisfaction is as significant as online service quality (Semeijin et al. 2005). Twelve bank managers asserted that understanding the needs of customers and delivering tailored products to build customers' trust in the bank, strengthens the bank-customer relationship. When asked about how would customers' trust in the bank helps to sell digital banking products to customers, majority of bank executives responded that trust on digital banking is a function of customers' perceived trustworthiness of bank. If customers trust the bank and its services, then they would intend to use its other digital mediums as well.

At the same time, bank executives from public sector banks expressed concern over the attitude of branch employees and organisational culture issues because they perceived that due to lack of motivation and heavy workload branch employees find it hard to provide individual attention to customers which in turn negatively affects the bank-customer relationship. Such a comment came from Banker 10:

We don't have an active action plan to ensure the positive frontline employee involvement with customers at the branch which is imperative to improve the overall performance of organisation and bank-customer relationship in digital era.

Interestingly, Banker 17 presented a completely different perspective on this issue and recognised that much more is needed to be done in India to make digital banking an indispensable part of people's life. When asked about the challenges in the way of establishing trust and the strong bank-customer relationship he responded:

With limited resources at branches, it's not feasible to handle a large pool of branch customers at once to convince them to adopt digital banking channel especially when majority of your customers lacks trust and competency to use technology for banking transactions.

The interviewee findings reveal that on the part of banks, efforts are required in the direction of segmenting the customers at the branch on the basis of their investments with the bank, banking needs, demographic profile, frequency of branch visits and then targeting the high-cost customers on a priority basis by offering them right channel mix. For instance, even previous studies conducted in the USA have documented that $58 \%$ of transactions at bank branch are 
generated by $18 \%$ of customers (Toit and Burns 2016). Bankers perceive that customer relationship management (CRM) at branch provides an opportunity to deepen the relationship with customers which in turn helps to convince the customers to adopt digital banking channels. Strong customer relationship with the customer-centric approach is suggested to create better chances for banks to reduce operational costs and improve their market share. Most of the bank executives emphasised that better customer relationship can make it possible for banks to create customer segments and target hightouch clients in bank branch to increase return on investment.

\section{Digitally driven branches with human touch}

In the digital era, banks are not only embracing technologybased banking channels to conduct transactions online but also focusing on modernising the bank branches. Various previous studies have already established that bank branches cannot be replaced in the present digital world (Baxter and Rigby 2014; Charniauski and Freeborn 2015; Brunier et al. 2015). During the current study, 15 bank executives reported that the banks can think of modernising branches with inbranch digital capabilities so that they can educate customers about modern technologies using the same platform which in turn helps to reduce the workload of branch staff. Previous studies have also demonstrated the importance of inbranch self-service technology to persuade non-adopter to adopt online banking channels (Berger 2009). It is evident that RBI's guidelines (2017) (May 2017) regarding digital banking outlets (e.g. SBI InTouch) have shifted the banking landscape in India. Banks in India are more inclined towards transforming existing branches than opening new ones.

When asked about the target customer segment, the majority of respondents were of the view that as a digital push initiative bank branch transformation intends to target predominantly the branch visitors who still prefer branch banking than digital channels. Few interviewees believed that even in the case of tech-savvy customers, the human touch is significant for customer satisfaction and behavioural intentions (Makarem et al. 2009). A participant from private sector bank gave the example of security and performancebased risk issues and how educating and informing customers about the security measures and benefits of digital banking channels through live demonstrations at the branch can build the trust of customers in digital banking (Martins et al. 2014).

Interestingly, while most of the bank managers recognised the significance of transforming the bank branches they also raised the concern over the cost of modernising and equipping all or most of the branches with self-service technology. One senior bank executive from a major public sector bank commented:
No doubt, all our branches need to be modernised and equipped with self-service kiosks and touch screens, but timing is not right due to high capital expenses involved. The best approach at this time can be to link digital banking channels to bank branches" (Banker 21).

\section{Discussion of findings}

Davis (1989) argues that perceived usefulness (PU) and perceived ease of use (PEOU) are the most significant determinants of technology adoption. TAM has established a strong and positive relationship between PU and technology adoption. Customers' behaviour intention has found to be influenced by perceived usefulness in a study conducted by Alalwan et al. (2017). Various other researchers have also highlighted the significant impact of perceived usefulness on customers' attitude and intention to use technology-enabled banking services (Wang et al. 2003; Juwaheer et al. 2012; Wentzel et al. 2013; Loureiro et al. 2014). Our research findings indicate that effective in-branch communication between branch staff and customers may significantly influence customers' attitude and intentions to use digital banking channels. The study reveals that once customers are communicated and informed personally about the usefulness, convenience and ease of using digital banking channels, they may perform all their future banking transactions online (Sathye 1999; Pikkarainen et al. 2004).

The proposed technological interventions and methods need to be simpler to understand; otherwise, customers would resist the change and continue with the traditional banking practices. Perceived ease of use has been identified as an important factor positively influencing the attitude of customers regarding technology-enabled banking services (Marakarkandy et al. 2017). More specifically individual's ability to use computer and technology positively influences the adoption of technology (Nath et al. 2013). The research findings depict that live demonstration in the digitally enabled branches with self-service kiosks can educate customers about how to use digital banking mediums which in turn will result in customers' acceptance. This finding is in line with the previous study conducted by Roy et al. (2017) where lack of self-efficacy (competence to use Internet and banking applications) was seen to negatively affect customers' perceived ease of use which consecutively was found to have the negative impact on customers' adoption of Internet banking in India.

The extended TAM supports the notion that branch service quality influences the customers' adoption of online banking services (Yap et al. 2010). There is a need for banks to focus on training their staff with interpersonal skills to become more productive and effective. The findings of the study show that 
effective customer financial advisory service at branch helps in attaining customers' trust. The quality of services delivered by branch staff influences the customers' adoption of online banking services. Previous studies have (Patricio et al. 2003; Yap et al. 2010) similarly highlighted that traditional service quality at branch leads to customers' satisfaction and trust in Internet banking services. Further, offline fulfilment for customer satisfaction is as significant as online service quality (Semeijin et al. 2005). Our research findings reveal that customer-centric efforts at bank branch can improve the customers' overall satisfaction and trust by developing and strengthening the personal relationship with customers. In other words, understanding the needs of customers and delivering tailored products to customers builds customers' trust in the bank and strengthens the bank-customer relationship. Trust on digital banking was reported as a function of customers' perceived trustworthiness of a bank (Fig. 2).

\section{Theoretical implications of the study}

The most prominent outcome of the present study pertains to the significance given to the in-branch customers' experience and changing role of bank branches to encourage customers to adopt digital channel for conducting future banking transactions. This study proposed a model that highlights the impact of in-branch customer engagement on their intention to adopt digital banking channels in India. The present study contributes to the literature by studying how personalisation and in-branch initiatives can facilitate to build customers' initial trust towards digital banking channels. In prior literature, some studies have been conducted on customers' behavioural factors (Malhotra and Singh 2010; Singh and Kaur 2011; Sinha and Mukherjee 2016) with regard to technology acceptance in the Indian banking industry. However, our study is first to explore and understand the significance of in-branch efforts of banks to migrate customers to adopt digital banking channels. Impact of in-branch communication with the customers about technology-driven efforts has hardly received any scholarly attention.

Various studies have reported a strong, positive relationship between perceived usefulness, ease of use and customers' attitude to adopt the technology (Wang et al. 2003; Juwaheer et al. 2012; Wentzel et al. 2013; Loureiro et al. 2014). Our research indicates that effective in-branch communication between branch staff and customers (Sathye 1999; Pikkarainen et al. 2004) and computer self-efficacy (Roy et al. 2017) developed through live demonstration in the digitally enabled branches may significantly influence the customers' attitude and intention to use digital banking channels.

The study reveals that branch service quality influences the customers' adoption of online banking services (Yap et al. 2010) by developing the trust of customers in e-banking services. Indian banks mainly public sector banks need to focus on training their staff with interpersonal skills to become more productive and effective. This finding is also supported by Kaur et al. (2012) in a previous study in which they highlighted the significance of training the bank employees as per bank's future strategies and plans to improve their job commitment.

Our study supports the view that offline fulfilment for customer satisfaction is as significant as online service quality (Semeijin et al. 2005). Further, we add to the literature by establishing a direct relationship between customers' trust in the bank and its e-banking services. The study emphasised the significance of customer relationship management (CRM) to identify the customer segments and target high-touch clients in a bank branch to increase return on investment.

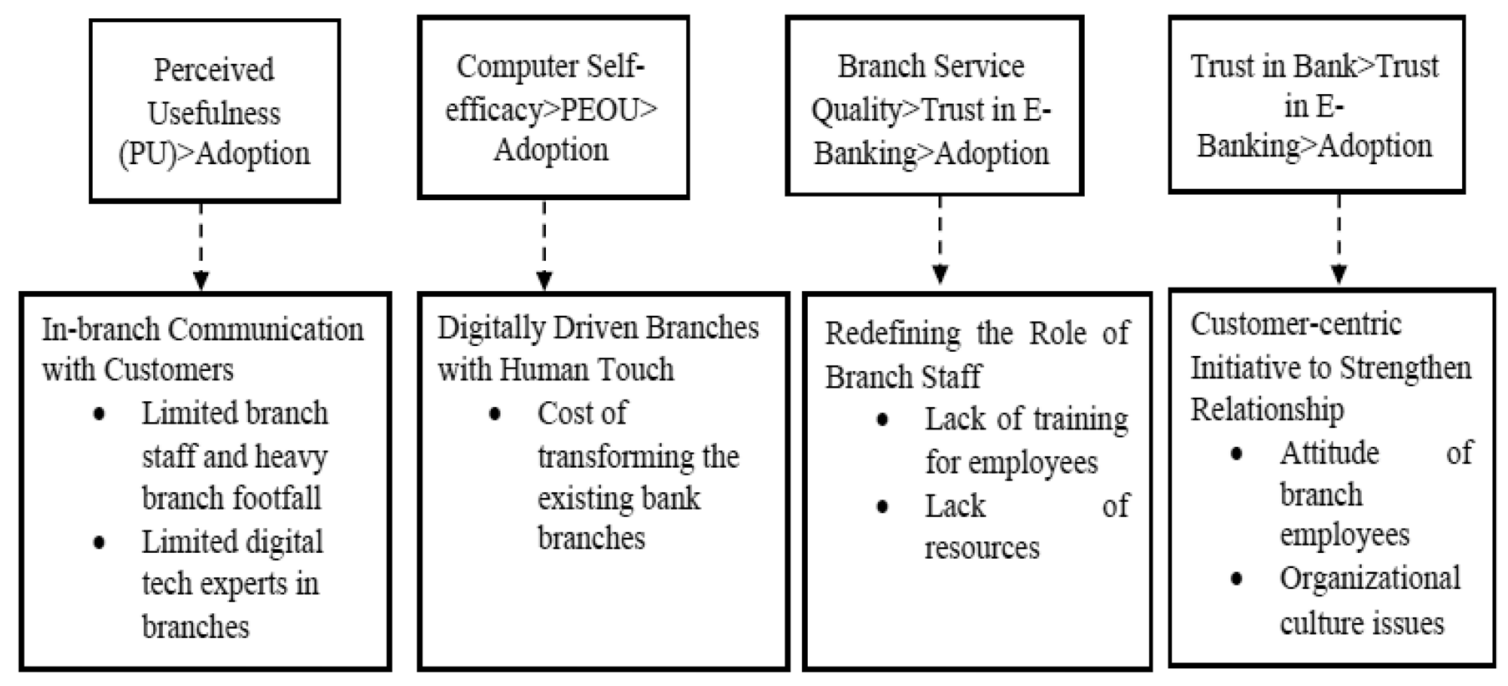

Fig. 2 Key in-branch efforts and associated challenges 


\section{Managerial implications}

In emerging countries, the challenge for the banking industry is to meet the needs of highly distinctive segments of customers in urban, semi-urban and rural areas. Against all the sunny reports released by banking industry regarding digital banking adoption in India, our research findings suggest that banks need to take serious in-branch initiatives to educate and make a majority of customers comfortable with digital channels for banking payments and transactions. The present study elucidates the need to transform future bank branches by identifying cost-effective strategies. Trust on digital banking has been identified as a function of customers' perceived trustworthiness of the bank. If customers trust the bank and its services, then they would intend to use the other digital mediums as well. Understanding and segmenting the branch visiting customers on the basis of how tech-savvy they are, their investments with the bank, banking needs, frequency of branch visits and then targeting the high-cost customers on a priority basis by offering them right channel mix (customer-centric approach) can make it possible for banks to increase return on investment and develop strong bank-customer relationship. Hence, banking regulators and industry should focus their attention to develop strong customer relationship management (CRM) practices in the branches to deepen the relationship with customers which in turn helps to build their trust in digital banking channels. One of the major hurdle in adopting the innovative digital banking channel is the lack of customers' trust. Hence banks need to build the trust of customers through providing them personalised banking services by identifying the different segments of customers and offering them the right channel mix.

The study also identifies various integrated cultural and organisational obstacles particularly in public sector banks which hinder the customers' adoption of digital banking. The banks need to focus the marketing strategy on enabling branches with digital capabilities, deploying more digitally trained employees in the branches to develop technological self-efficacy among customers to use innovative digital banking channels which in turn can help to reduce the digital divide in India.

This study draws the attention of the bank managers towards the need to design appropriate in-branch communication strategy by identifying various segments of branch visiting customers and make special efforts for the training of frontline branch staff (Cooper et al. 1994) to instil expertise not only in banking technology but also in communication skills. Further, our interview data suggest that banks in India are concerned about the high cost involved in branch digitisation. Banks need to understand that return on investment in technology would occur in the long run only if the large chunk of its customers migrates to digital channels and that is possible with the transformation of existing branch service model (Tang 2016). Migration of customers to digital banking channels in India calls for developing branch transformation strategy with the focus on a customer-centric approach. However, the branch transformation is seen to face various challenges, especially in the context of public sector banks in India. These issues raise the urgent need for focusing on improving in-branch practices of banks to convince customers to migrate to digital banking channels.

Due to COVID-19 maintaining physical distancing and providing in-branch services to customers is another challenge for banks in India with high number of branch visiting customers. In this strange time, banks can put a restriction on number of customers entering the branch at a time with flexible working hours to spread customer footfall and rotating staff. Additionally, visit by appointment only could be another alternative for banks to ensure the safety of customers and staff. The banks can also develop integrated services for customers in rural areas where business correspondents and India Post channel can provide banking services using digital tools at the door step of the customers with the purpose of reducing the number of customers visiting the branch.

\section{Limitations of the study and future research}

The study significantly contributes to the literature but with few limitations which can be addressed in future research. The present study concentrates on bank managers perceptions about in-branch efforts. For future research, it would be fruitful to trace out the perceptions of customers regarding the impact of in-branch efforts on their adoption of digital banking channels. Further, insights from this study could be used to frame a model for the impact of in-branch initiatives on customers' adoption of digital banking that can be empirically tested. Future research can examine the impact of COVID-19 on digital banking and mobile payments acceptance in India as the current pandemic situation has encouraged customers to access remote banking services. Another avenue for future research is exploring the potential of modern agent network-based payment models in reaching out financially excluded section and examining whether these new models are opportunity or threat to the established digital channels.

\section{Appendix}

See Table 3. 
Table 3 Interview protocol/questions framework

Perception regarding technological interventions in the banking industry

1. Changes in working experience due to technology

2. Impact of digital banking on branch footfall

3. Banking needs of branch visiting customers and employees attitude

Development of In-Branch Strategies

1. In-Branch marketing strategy of bank

2. Overall In-branch marketing budget

3. Allocation of resources/culture in branch

4. Customer Relationship Management (CRM) practices at branch

Implementation of In-Branch strategies

1. Identification of customer segments

2. Resource constraints (if any)

3. Branch staff training

\section{References}

Accola, J. 1996. Bank pays customers to use ATM, Denver Rocky Mountain News, 25 April, pp. 3b.

Alalwan, A.A., Y.K. Dwivedi, and N.P. Rana. 2017. Factors influencing adoption of mobile banking by Jordanian bank customers: Extending UTAUT2 with trust. International Journal of Information Management 37 (3): 99-110.

Alalwan, A.A., Y.K. Dwivedi, N.P. Rana, and M.D. Williams. 2016. Consumer adoption of mobile banking in Jordan: examining the role of usefulness, ease of use, perceived risk and self-efficacy. Journal of Enterprise Information Management 29 (1): 118-139.

AVAYA, 2017. "The Avaya-commissioned Customer Experience in Banking 2017 Report", available at: https://www.avaya.com/en/ about-avaya/newsroom/news-releases/2017/pr-aus-170810/(acces sed 10 January 2018).

Bakshi, I. 2016. Cash deals cost 1.7\% of GDP: Visa, available at: https ://www.business-standard.com/article/economy-policy/cash-deals -cost-1-7-of-gdp-visa-116100500617_1.html(accessed 20 November 2017).

Banu, A.M., N.S. Mohamed, and S. Parayitam. 2019. Online banking and customer satisfaction: Evidence from India. Asia-Pacific Journal of Management Research and Innovation 15 (1-2): 68-80.

Bashir, I., and C. Madhavaiah. 2015. Trust, Social Influence, SelfEfficacy, Perceived Risk and Internet Banking Acceptance: An Extension of Technology Acceptance Model in Indian Context. Metamorphosis 14 (1): 25-38.

Baxter, M. and D. Rigby. 2014. Rethinking the Bank Branch in a Digital World, available at: https://hbr.org/2014/09/rethinking -the-bank-branch-in-a-digital-world(accessed 12 December 2017).

Berger, S.C. 2009. Self-service technology for sales purposes in branch banking: The impact of personality and relationship on customer adoption. International Journal of Bank Marketing 27 (7): 488-505.

Brunier, F., D. Patsch, and F. Stradtmann. 2015. Transforming the Banking Branch", available at: https://www.accenture.com/t20160321T 020410Z_w__in- en/_acnmedia/Accenture/Conversion-Assets/ DotCom/Documents/Global/PDF/Strategy_7/Accenture-StrategyTransforming-Banking-Branch.pdf (accessed 15 January 2018).

Charniauski, A. and L. Freeborn. 2015. Branch Transformation in a Digital World, available at: https://www.idc.com/getdoc.jsp?conta inerId=FIBA01X(accessed 15 January 2018).

Chiou, J.S., and C.C. Shen. 2012. The antecedents of online financial service adoption: the impact of physical banking services on
Internet banking acceptance. Behaviour \& Information Technology 31 (9): 859-871.

Cognizant 20-20 Insights. 2016. Transforming the Branch: What Banks Need to Do, available at: https://www.cognizant.com/whitepaper s/transforming-the-branch-what-banks-need-to-do-codex2217.pdf (accessed 10 February 2018).

Cooper, W.W. 1994. Data envelopment analysis: Survey and interpretation, Operations Research:Communication of the Operations Research Society of Japan.

Dallerup, K., S. Jayantilal, G. Konov, H. Stockmeier, and A. Legradi. 2018. The bank branch for the digital age, available at: https:// www.mckinsey.com/industries/financial-services/our-insights/abank-branch-for-the-digital-age (accessed 13 September 2018).

Davis, F.D. 1989. Perceived usefulness, perceived ease of use, and user acceptance of information technology, MIS quarterly, 319-340.

Devi Juwaheer, T., S. Pudaruth, and P. Ramdin. 2012. Factors influencing the adoption of internet banking: a case study of commercial banks in Mauritius. World Journal of Science, Technology and Sustainable Development 9 (3): 204-234.

DeYoung, R., W.W. Lang, and D.L. Nolle. 2007. How the Internet affects output and performance at community banks. Journal of Banking \& Finance 31 (4): 1033-1060.

Durkin, M.G., and B. Howcroft. 2003. Relationship marketing in the banking sector: the impact of new technologies. Marketing Intelligence \& Planning 21 (1): 61-71.

Eriksson, K., K. Kerem, and D. Nilsson. 2005. Customer acceptance of internet banking in Estonia. International Journal of bank marketing 23 (2): 200-216.

Featherman, M.S., and P.A. Pavlou. 2003. Predicting e-services adoption: a perceived risk facets perspective. International Journal of Human-Computer Studies 59 (4): 451-474.

Gartner 2019. Gartner Predicts Indian Banking and Securities IT Spending to Grow $9 \%$ in 2020, available at: https://www.gartn er.com/en/newsroom/press-releases/2019-06-18-gartner-predictsindian-banking-and-securities-it-spe (accessed 21 March 2020).

Goff, B.G., J.S. Boles, D.N. Bellenger, and C. Stojack. 1997. The influence of salesperson selling behaviors on customer satisfaction with products. Journal of Retailing 73 (2): 171-183.

Harden, G. 2002. E-banking comes to town: Exploring how traditional UK high street banks are meeting the challenge of technology and virtual relationships. Journal of Financial Services Marketing 6 (4): 323-332.

He, D., K. You, W. Li, and J. Wu. 2019. Determinants of Technology Adoption: Evidence from the Chinese Banking Industry, Emerging Markets Finance and Trade, 1-23. 
Healy, M., and C. Perry. 2000. Comprehensive criteria to judge validity and reliability of qualitative research within the realism paradigm. Qualitative Market Research: An International Journal 3 (3): 118-126.

Hirschman, E. C. 1986. Humanistic inquiry in marketing research: philosophy, method, and criteria, Journal of Marketing Research, 237-249.

Howcroft, B., R. Hamilton, and P. Hewer. 2002. Consumer attitude and the usage and adoption of home-based banking in the United Kingdom. International Journal of Bank Marketing 20 (3): 111-121.

Ibrahim, E.E., M. Joseph, and K.I. Ibeh. 2006. Customers' perception of electronic service delivery in the UK retail banking sector", International Journal of Bank Marketing, 24(7), 475-493. In Qualitative data analysis: a sourcebook of new methods. Sage publications.

Joyce, L. 2017. Digital Bank Transformation: The Evolution of Branch Banking, available at: https://thefinancialbra nd.com/67893/banking-branch-network-strategy-design/(acces sed 23 January 2018).

Karjaluoto, H., A.A. Shaikh, H. Saarijärvi, and S. Saraniemi. 2018. How perceptual value drives the use of mobile financial services apps? International Journal of Information Management 47: 252-261.

Karjaluoto, H., A.A. Shaikh, M. Leppäniemi, and R. Luomala. 2019. Examining consumers' usage intention of contactless payment systems. International Journal of Bank Marketing 38 (2): 332-351.

Kaur, G., R.D. Sharma, and N. Mahajan. 2012. Exploring customer switching intentions through relationship marketing paradigm. International Journal of Bank Marketing 30 (4): 280-302.

King, W.R., and J. He. 2006. A meta-analysis of the technology acceptance model. Information \& Management 43 (6): 740-755.

Kumar Sharma, S., and S. MadhumohanGovindaluri. 2014. Internet banking adoption in India: structural equation modeling approach. Journal of Indian Business Research 6 (2): 155-169.

Kumar, A. 2019. A Refreshed 'Digital India' Programme will Play Critical Role in the Pursuit of $\$ 5$ Trillion Economy, available at: https://economictimes.indiatimes.com/small-biz/startups/newsb uzz/a-refreshed-digital-india-programme-will-play-critical-rolein-the-pursuit-of-5-trillion-economy/articleshow/70067053. $\mathrm{cms}$ ?from $=$ mdr (accessed 20 March 2020).

Lee, K.C., I. Kang, and D.H. McKnight. 2007. Transfer from offline trust to key online perceptions: an empirical study. IEEE Transactions on Engineering Management 54 (4): 729-741.

Luchetti, G. 2017. The future of banking will include brick-and-mortar branches, available at: https://www.scmp.com/business/bankingfinance/article/2101363/future-banking-will-include-brick-andmortar-branches(accessed 21 January 2018).

Luo, X., H. Li, J. Zhang, and J.P. Shim. 2010. Examining multi-dimensional trust and multi-faceted risk in initial acceptance of emerging technologies: An empirical study of mobile banking services. Decisionsupport systems 49 (2): 222-234.

Lymperopoulos, C., and I.E. Chaniotakis. 2004. Branch employees' perceptions towards implications of e-banking in Greece. International Journal of Retail \& Distribution Management 32 (6): 302-311.

Machauer, A., and S. Morgner. 2001. Segmentation of bank customers by expected benefits and attitudes. International Journal of Bank Marketing 19 (1): 6-18.

Makarem, S.C., S.M. Mudambi, and J.S. Podoshen. 2009. Satisfaction in technology-enabled service encounters. Journal of Services Marketing 23 (3): 134-144.

Malhotra, P., and B. Singh. 2010. An analysis of Internet banking offerings and its determinants in India. Internet Research 20 (1): 87-106.
Marakarkandy, B., N. Yajnik, and C. Dasgupta. 2017. Enabling internet banking adoption: An empirical examination with an augmented technology acceptance model (TAM). Journal of Enterprise Information Management 30 (2): 263-294.

Loureiro, Maria Correia, H. Rudiger Kaufmann, and S. Rabino. 2014. Intentions to use and recommend to others: an empirical study of online banking practices in Portugal and Austria. Online Information Review 38 (2): 186-208.

Marous, J. 2013. Migrating Banking Customers to Digital Channels, available at: https://thefinancialbrand.com/37287/migrating-banki ng-customers-to-digital/(accessed 15 January 2018).

Martins, C., T. Oliveira, and A. Popovič. 2014. Understanding the Internet banking adoption: A unified theory of acceptance and use of technology and perceived risk application. International Journal of Information Management 34 (1): 1-13.

Mayring, P. 2000. Qualitative content analysis. Qualitative Social Research Forum 1 (2):20. https://www.qualitative-research.net/ index.php/fqs/article/view/1089/2385.

McKinsey Consumer Insight 2016. Reimagining the bank branch for the digital era, available at: https://www.mckinsey.com/industries /financial-services/our-insights/reimagining-the-bank-branch-forthe-digital-era(accessed 10 December 2017).

Miles, M.B., and A.M. Huberman. 1984. Qualitative data analysis: A sourcebook of new methods. London: Sage.

Montazemi, A.R., and H. Qahri-Saremi. 2015. Factors affecting adoption of online banking: A meta-analytic structural equation modeling study. Information \& Management 52 (2): 210-226.

Mukherjee, A., and P. Nath. 2003. A model of trust in online relationship banking. International Journal of Bank Marketing 21 (1): $5-15$.

Myers, J.B., A.D. Pickersgill, and E.S. Van Metre. 2004. Steering customers to the right channels. McKinsey Quarterly 4 (3): 36-47.

Nath, R., K.T. Bhal, and G.T. Kapoor. 2013. Factors influencing IT adoption by bank employees: An extended TAM approach. Vikalpa 38 (4): 83-96.

Normalini, M.K., and T. Ramayah. 2017. Trust in internet banking in Malaysia and the moderating influence of perceived effectiveness of biometrics technology on perceived privacy and security. Journal of Management Sciences 4 (1): 3-26.

Osho, G.S. 2008. How technology is breaking traditional barriers in the banking industry: Evidence from financial management perspective. European Journal of Economics, Finance, and Administrative Sciences 11 (3): 15-21.

Pandey, N. 2018. Only 16\% of rural users access Internet for digital payments: Report, available at: https://www.livemint.com/Politics/ PhY0kTxoJqq6U9GISIpSaK/Only-16-of-rural-users-access-Inter net-for-digital-payments.html(accessed 5 January 2018).

Patel, K.J., and H.J. Patel. 2018. Adoption of internet banking services in Gujarat: An extension of TAM with perceived security and social influence. International Journal of Bank Marketing 36 (1): 147-169.

Patricio, L., R.P. Fisk, and J. Falcao e Cunha. 2003. Improving satisfaction with bank service offerings: measuring the contribution of each delivery channel. Managing Service Quality: An International Journal 13 (6): 471-482.

Pikkarainen, T., K. Pikkarainen, H. Karjaluoto, and S. Pahnila. 2004. Consumer acceptance of online banking: An extension of the technology acceptance model. Internet Research 14 (3): 224-235.

Poon, W.C. 2007. Users' adoption of e-banking services: the Malaysian perspective. Journal of Business \& Industrial Marketing 23 (1): 59-69.

Rajan, R. 2015. Hindi and Other Indian Languages can act as a bridge between Banker and Customer: Dr Raghuram G. Rajan, Governor, Reserve Bank of India, June 19, 2015, available at: https ://rbi.org.in/scripts/BS_PressReleaseDisplay.aspx?prid=34227. 
Rawashdeh, A. 2015. Factors affecting adoption of internet banking in Jordan: Chartered accountant's perspective. International Journal of Bank Marketing 33 (4): 510-529.

Reserve Bank of India 2017. Reserve Bank of India Annual Report 2016-17, available at: https://www.thehindubusinessline.com/ multimedia/archive/03196/RBI_Annual_Report_3196461a.PDF (accessed 6 January 2018).

Rotchanakitumnuai, S., and M. Speece. 2003. Barriers to Internet banking adoption: A qualitative study among corporate customers in Thailand. International Journal of Bank Marketing 21 (6/7): 312-323.

Roy, S.K., M.S. Balaji, A. Kesharwani, and H. Sekhon. 2017. Predicting Internet banking adoption in India: A perceived risk perspective. Journal of Strategic Marketing 25 (5-6): 418-438.

Safeena, R., A. Kammani, and H. Date. 2014. Assessment of internet banking adoption: An empirical analysis. Arabian Journal for Science and Engineering 39 (2): 837-849.

Sánchez-Torres, J.A., F.J.A. Canada, A.V. Sandoval, and J.A.S. Alzate. 2018. E-banking in Colombia: factors favouring its acceptance, online trust and government support. International Journal of Bank Marketing 36 (1): 170-183.

Sarel, D., and H. Marmorstein. 2002. Migrating customers to new distribution channels: The role of communication. Journal of Financial Services Marketing 6 (3): 254-266.

Sarel, D., and H. Marmorstein. 2003. Marketing online banking services: The voice of the customer. Journal of Financial Services Marketing 8 (2): 106-118.

Sathye, M. 1999. Adoption of Internet banking by Australian consumers: an empirical investigation. International Journal of Bank Marketing 17 (7): 324-334.

Schofield, M. and S. Chew. 2013. Future of the bank branch in Asia: Redesigning footprint and format, available at: http://www.bain. com/publications/articles/future-of-the-bank-branch-in-asia-redes igning-footprint-and-format.aspx(accessed 6 January 2018).

Semeijn, J., A.C. Van Riel, M.J. Van Birgelen, and S. Streukens. 2005. E-services and offline fulfilment: how e-loyalty is created. Managing Service Quality: An International Journal 15 (2): 182-194.

Shaikh, A.A., M.D. Alharthi, and H.O. Alamoudi. 2020. Examining key drivers of consumer experience with (non-financial) digital services-An exploratory study. Journal of Retailing and Consumer Services 55: 102073.

Shaikh, A.A., and H. Karjaluoto. 2016. Some misconceptions concerning digital banking and alternative delivery channels. International Journal of E-Business Research 12 (3): 1-16.

Shetty, S. 2017. Gartner Says The Transition of The Indian Banking Sector To Cashless Society is Driving Increased Technology Investments, available at: https://www.gartner.com/newsroom/ id/3827164 (accessed 10 January 2018).

Singh, J., and G. Kaur. 2011. Customer satisfaction and universal banks: an empirical study. International Journal of Commerce and Management 21 (4): 327-348.

Sinha, I., and S. Mukherjee. 2016. Acceptance of technology, related factors in use of off branch e-banking: an Indian case study. The Journal of High Technology Management Research 27 (1): $88-100$.

Sukkar, A.A., and H. Hasan. 2005. Toward a model for the acceptance of internet banking in developing countries. Information Technology for Development 11 (4): 381-398.

Susanto, A., H. Lee, H. Zo, and A.P. Ciganek. 2013. User acceptance of Internet banking in Indonesia: initial trust formation. Information Development 29 (4): 309-322.

Szopiński, T.S. 2016. Factors affecting the adoption of online banking in Poland. Journal of BusinessResearch 69 (11): 4763-4768.

Takieddine, S., and J. Sun. 2015. Internet banking diffusion: A countrylevel analysis. Electronic Commerce Research and Applications 14 (5): 361-371.
Tang, D. 2016. Branch transformation in the digital era, available at: https://www.ibm.com/industries/banking-financial-markets/resou rces/branch-transformation-digital-era/ (accessed 13 March 2018).

Taylor, S., and P.A. Todd. 1995. Understanding information technology usage: A test of competing models. Information Systems Research 6 (2): 144-176.

The Economic Times 2018. Acute urban-rural divide in Internet penetration in India: Report, available at: https://economictimes. indiatimes.com/tech/internet/acute-urban-rural-divide-in-inter net-penetration-in-india-report/articleshow/62997468.cms(acces sed 24 December 2017).

The Economic Times. 2018. Number of Adult Indians with Bank Accounts Rises to $80 \%$, available at: https://economictimes.india times.com/industry/banking/finance/banking/number-of-adult -indians-with-bank-accounts-rises-to-80/articleshow/63838930. cms(accessed 21 March 2020).

Tiwari, R. 2019. Contribution of cyber banking towards digital India: A way forward. Khoj. An International Peer Reviewed Journal of Geography 6 (1): 46-52.

Tobbin, P. 2012. Towards a model of adoption in mobile banking by the unbanked: A qualitative study. Info 14 (5): 74-88.

Toit, G. and M. Burns. 2016. Customer Loyalty in Retail Banking: Global Edition 2016, available at: http://www.bain.com/publicatio ns/articles/customer-loyalty-in-retail-banking-2016.aspx(accessed 10 January 2018).

Vater, D., J. Engelhardt, J. Fielding, and R. Hatherall. 2019. As Banks Pursue Digital Transformation, Many Struggle to Profit from It, available at: https://www.bain.com/insights/as-banks-pursue-digit al-transformation-many-struggle-to-profit-from-it/ (accessed 24 March 2020).

Waite, K., and T. Harrison. 2002. Consumer expectations of online information provided by bank websites. Journal of Financial Services Marketing 6 (4): 309-322.

Walker, R.H., and L.W. Johnson. 2006. Why consumers use and do not use technology-enabled services. Journal of Services Marketing 20 (2): 125-135.

Wang, Y.S., Y.M. Wang, H.H. Lin, and T.I. Tang. 2003. Determinants of user acceptance of Internet banking: an empirical study. International Journal of Service Industry Management 14 (5): 501-519.

Wentzel, J.P., K.S. Diatha, and V.S.S. Yadavalli. 2013. An application of the extended Technology Acceptance Model in understanding technology-enabled financial service adoption in South Africa. Development Southern Africa 30 (4-5): 659-673.

World Bank. 2017. The Global Findex Database- Measuring Financial Inclusion and the Fintech Revolution", available at:https://globa lfindex.worldbank.org/sites/globalfindex/files/2018-04/2017\%20 Findex\%20full\%20report_0.pdf(accessed 21 March 2020).

Yap, K.B., D.H. Wong, C. Loh, and R. Bak. 2010. Offline and online banking-where to draw the line when building trust in e-banking? International Journal of Bank Marketing 28 (1): 27-46.

Yiga, C., and K.J. Cha. 2014. Toward understanding the importance of trust in influencing Internet banking adoption in Uganda. Information Development 32 (3): 622-636.

$\mathrm{Yu}, \mathrm{D}$. and J. Hughes. 2016., Struggle for Banks: Migrate Customers to Digital, available at: http://news.gallup.com/businessjo urnal/196778/struggle-banks-migrating-customers—digital.aspx (accessed 10 November 2017).

Publisher's Note Springer Nature remains neutral with regard to jurisdictional claims in published maps and institutional affiliations. 